\title{
Mondiale regelgeving?
}

Willem Buijink

De universiteit waar ik werk organiseert al een aantal jaren een 'Honours'-programma voor goede Bachelorstudenten. Die studenten, ze moeten goed gepresteerd hebben in het eerste jaar van hun Bachelorprogramma, worden uitgenodigd om vier extra vakken te volgen in de hogere Bachelorjaren. De vier vakken mogen de studenten niet kiezen uit de Honours programmavakken van de eigen Faculteit. Het doel is verbreding van de kennis van de studenten die deelnemen. Door de selectie is het aantal studenten dat een docent tegenover zich ziet zitten klein. Niet lang geleden heb ik twee jaar een vak in dat Honours programma gedoceerd. Ik behandelde de geschiedenis van het meten van het resultaat van ondernemingen, van externe verslaggeving dus, inclusief accountantscontrole en de regulering van verslaggeving. Daarbij ging het niet diepgaand over de techniek van de meting van resultaat. Wat ik wilde laten zien waren de redenen achter het ontstaan van resultaatmeting van ondernemingen. Eigendomsrechten maken het ontstaan van ondernemingen mogelijk. Hoe ontstonden eigendomsrechten? Eigendomsrechten maken ook markten mogelijk. Hoe is dat gegaan? Waarom ontstaan ondernemingen in markten? Waar ontstaat het idee om aandelen als eigendomsrechten te gaan verhandelen? Waarom ontstaat een kapitaalmarkt? Waar en waarom ontstond het idee van beperkte aansprakelijkheid van aandeelhouders en de vennootschap als vorm van onderneming? Waar ontstaan banken, die leningen gaan verstrekken aan ondernemingen? Waar en waarom ontstaat dubbel boekhouden als systeem van meting van het ondernemingsresultaat? Waar en waarom ontstond externe accountantscontrole van het ondernemingsresultaat. Al deze zaken veronderstellen de ontwikkeling van een rechtssysteem, van regelgeving. Hoe verliep die ontwikkeling en waarom is die ontwikkeling van regelgeving juist op het terrein van het meten van ondernemingsresultaat in de meer recente periode zo snel gegaan? De behandeling van dit soort vragen laat de context zien waarin resultaatmeting van ondernemingen ontstaat en werpt ook licht op de vorm die resultaatmeting van onder- nemingen aangenomen heeft. In normale cursussen over externe verslaggeving worden dit soort vragen maar heel summier behandeld. Dat is jammer, want daardoor laten we de kans lopen onze studenten te laten kennis maken met fundamentele bijdragen over de context van externe verslaggeving, en dus ook over externe verslaggeving zelf, van intellectuele reuzen als Hayek (over markten), Coase (over ondernemingen), Alchian (over markten), Stigler (over regelgeving), De Roover en Yamey (beiden over de geschiedenis van markten en de onderneming, en van externe verslaggeving), om er maar een paar te noemen.

Ook in de algemene academische accountancy tijdschriften is aandacht voor deze vragen bijna afwezig. Dat maakt de discussies daarin ook enger dan wenselijk is. Maar in die tijdschriften lijkt gelukkig een kentering aan de gang. Niet alleen in accountancytijdschriften, maar in ook financiering- en economietijdschriften ontstaat weer meer aandacht voor deze vragen (zie bijvoorbeeld Waymire (2009) en Malmendier (2008)).

Eén aspect van de literatuur die ingaat op de bovenstaande vragen brengt mij bij mijn eigenlijke thema: wat is de beste manier om het proces van regulering van externe verslaggeving en accountantscontrole te organiseren. Het is opvallend dat over een lange periode bezien de innovaties op de terreinen die de vragen bestrijken, marktinstituties, ondernemingsvormen, verslaggevingtechnieken, lokaal ontstaan zijn en vormgegeven werden. Ze verspreidden zich daarna in een proces van competitie waarin de meest geschikte innovaties overleefden. Een voorbeeld hiervan is het ontstaan van de ondernemingsvorm 'besloten vennootschap met beperkte aansprakelijkheid'. Die ondernemingsvorm is in Frankrijk en Duitsland ontstaan, heeft daar zijn nut bewezen en is dan later ook in landen als Engeland en Nederland ingevoerd. Het proces van uitvinding van technieken van externe verslaggeving en accountantscontrole zelf was, terugkijkend in de tijd, ook een proces van lokale innovaties die vervolgens, na gebleken geschiktheid, na een proces van compe- 
titie, breder in gebruik raakten. Ook toen regelgeving op dit terrein in individuele landen ontstond, bleef het proces van competitie ten dele bestaan. Binnen landen is er dan minder competitie tussen innovaties. Maar tussen landen, tussen regelgevers dus, zeker nog wel.

Kijkend naar het proces van regulering van externe verslaggeving en accountantscontrole moet vastgesteld worden dat dit proces van lokale ontwikkeling, competitie en dan bredere toepassing, binnen en tussen landen aan het verdwijnen is. Vorm en inhoud van externe verslaggeving en accountantscontrole worden nu steeds meer centraal bedacht, denk aan de EU, en dan meteen breed ingevoerd. Die tendens van centralisatie lijkt op beide gebieden, externe verslaggeving en accountantscontrole, zelfs te gaan leiden tot mondiale regelgeving.

Dat is een ontwikkeling die niet zonder risico's is. Wat bij supranationale, mondiale, regulering wegvalt, is competitie tussen lokale innovaties op de terreinen van externe verslaggeving en accountantscontrole. De keuzes van regelgevers op het terrein van externe verslaggeving en accountantscontrole worden dan niet meer door een proces van competitie getoetst.

De recente bankencrisis laat zien hoe belangrijk het leereffect is van het laten bestaan van mogelijkheden voor lokale regels. Spanje bijvoorbeeld eist van haar banken, tegen supranationale regelgevers in, het vormen van anticyclische voorzieningen. In Canada bijvoorbeeld bestaat, tegen internationale 'druk' in, een grotere scheiding van zaken- en algemene banken. In Spanje en Canada lijken banken beter bestand tegen de crisis, precies door deze lokale keuzes. Echte mondiale regulering van het bankwezen, en daar wordt nu vaak voor gepleit, zal ons per definitie het zicht ontnemen op de effecten van lokale innovaties en praktijken.

Het risico van supranationale en mondiale regulering is dat door die regelgevers verkeerde keuzes gemaakt worden, zonder dat dit duidelijk kan worden omdat concurrerende keuzes niet meer bestaan. Dat risico is extra groot als regelgevers, en dat is zo op het terrein van externe verslaggeving, regels eerder normatief ontwikkelen. Dat wil zeggen,

\section{Literatuur}

Waymire, G., 2009, Exchange guidance is the fundamental demand for accounting, in: The Accounting Review, 84, pp. 53-62.

- Malmendier, U., 2009, Law and finance 'at the origin', working paper, forthcoming in J ournal of Economic Perspectives zonder echt moeite te doen om in te laten schatten wat de echte kwaliteit is van hun keuze. Regelgeving op dit terrein is heel vaak niet 'evidence based'. Dit alles geldt voor de keuze op het niveau van individuele items in de jaarrekening, maar ook voor macrokeuzes op dit terrein. Een voorbeeld daarvan is de keuze van IASB en FASB voor een balansgerichte benadering van externe verslaggeving met de bijbehorende nadruk op reële waardewaardering. Het zal heel moeilijk worden om de juistheid van deze keuze nog te toetsen bij een mondiale invoering ervan als IASB en FASB hun overleg hierover afgerond hebben. Deze keuze heeft grote gevolgen voor resultaatmeting. Zijn gebruikers van jaarrekeningen daar echt bij gebaat? Goed beschouwd weten we dat niet en bij mondiale regelgeving valt de mogelijkheid weg om gevolgen van de keuze goed te observeren. Er zal geen 'controlegroep' zijn.

Wat is dan het juiste niveau van regulering van externe verslaggeving in brede zin: het niveau van individuele landen, het niveau van groepen van landen, zoals de Europese Unie, of mondiaal? Mondiale regelgeving, zoals nu door IASB en FASB nagestreefd op het terrein van externe verslaggeving, is erg risicovol. Het legt competitie tussen innovaties in externe verslaggeving stil. Bij mondiale regulering van accountantscontrole zal zich hetzelfde probleem voordoen. Datzelfde risico bestaat ook bij supranationale regulering van verslaggeving en accountantscontrole binnen groepen van landen zoals de EU. Maar in dat geval blijft er in ieder geval nog waardevolle competitie tussen de groepen van landen bestaan. Bedenkers van supranationale regelgeving zouden er in ieder geval goed aan doen om de regelgeving zo in te richten dat de deelnemende landen zeker ruimte houden om individuele keuzes te maken waarvan de kwaliteit dan over tijd beoordeeld kan worden.

Bestudering van de geschiedenis van externe verslaggeving en accountantscontrole, daar begon ik mee, laat het belang zien van competitie tussen innovaties op deze terreinen. Een belangrijke taak van regelgevers is deze competitie in innovaties in ieder geval te laten bestaan. Een eerste stap moet zijn: beseffen dat mondiale regelgeving er op deze terreinen beter niet komt.

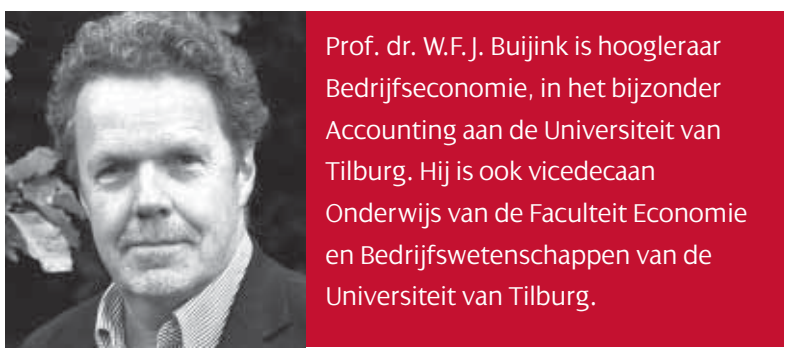

